\title{
Infectious pancreatic necrosis virus (IPNV) strain with genetic properties associated with low pathogenicity at Finnish fish farms
}

\author{
Anna Maria Eriksson-Kallio ${ }^{1, *}$, Riikka Holopainen ${ }^{2}$, Satu Viljamaa-Dirks ${ }^{3}$, \\ Pia Vennerström ${ }^{1}$, Hanna Kuukka-Anttila ${ }^{4}$, Perttu Koski ${ }^{5}$, Tuija Gadd ${ }^{2}$ \\ ${ }^{1}$ Finnish Food Safety Authority Evira, Research and Laboratory Department, \\ Production Animal and Wildlife Health Research Unit, Mustialankatu 3, 00790 Helsinki, Finland \\ ${ }^{2}$ Finnish Food Safety Authority Evira, Research and Laboratory Department, Veterinary Virology Research Unit, \\ Mustialankatu 3, 00790 Helsinki, Finland \\ ${ }^{3}$ Finnish Food Safety Authority Evira, Research and Laboratory Department, \\ Production Animal and Wildlife Health Research Unit, PO Box 92, 70701 Kuopio, Finland \\ ${ }^{4}$ Finnish Food Safety Authority Evira, Control Department, Animal Health and Welfare Unit, Mustialankatu 3, \\ 00790 Helsinki, Finland \\ ${ }^{5}$ Finnish Food Safety Authority Evira, Research and Laboratory Department \\ Production Animal and Wildlife Health Research Unit, PO Box Elektroniikkatie 3, 90590 Oulu, Finland
}

\begin{abstract}
Infectious pancreatic necrosis (IPN) is a contagious viral disease of fish that causes economic losses in aquaculture worldwide. In Finland, IPN virus (IPNV) has been isolated since 1987 from adult fish showing no signs of clinical disease at fish farms located in the coastal areas of the Baltic Sea. The inland area of Finland, however, remained free of IPN until 2012, when fish on several rainbow trout farms were diagnosed IPNV-positive. The fish mortalities detected at the farms were low, but clinical signs and histopathological changes typical for IPNV infection were seen in juvenile salmonids. IPNV was isolated at high water temperatures up to $22^{\circ} \mathrm{C}$. In 2013 and 2014, IPNV detections continued at inland farms, indicating that infections have spread. The aim of this study was to describe the epidemiology of the outbreak and to characterise the Finnish inland IPNV isolates using histopathological, immunohistochemical and genetic approaches. In order to determine the epidemiological origin of the inland IPNV infections, the partial viral capsid protein (VP2) gene sequences of the inland IPNV isolates were compared with the sequences of the isolates from the coastal farms. Based on the genetic analysis, the inland isolates belong to IPNV Genogroup 2 (Serotype A3/Ab), and the origin of the isolates appears to be one or several coastal fish farms.
\end{abstract}

KEY WORDS: IPNV $\cdot$ Rainbow trout $\cdot$ High water temperature $\cdot$ Genogroup $2 \cdot$ VP2 gene

\section{INTRODUCTION}

Infectious pancreatic necrosis virus (IPNV) is the causal agent of one of the most important viral diseases of farmed salmonid fishes, infectious pancreatic necrosis (IPN). IPNV is a small double-stranded RNA virus belonging to the family Birnaviridae, genus Aquabirnavirus (Dobos 1995). The host range of aquabirnaviruses includes several species of fish,

\footnotetext{
${ }^{*}$ Corresponding author: annamaria.eriksson-kallio@evira.fi
}

crustaceans and molluscs (Rodriguez Saint-Jean et al. 2003). The rainbow trout is considered one of the most susceptible species to IPN (Hill 1982). IPNV causes disease in young salmonids, with clinical signs such as darkening of the skin, exophthalmia, abdominal swelling and aberrant swimming behaviour. Mortalities vary, with mortality rates of up to $100 \%$ described in young first-feeding fry (Smail et al. 1992, Reno 1999).

(C) The authors 2016. Open Access under Creative Commons by Attribution Licence. Use, distribution and reproduction are unrestricted. Authors and original publication must be credited. 
The pathogenicity of the virus depends on the viral isolate, as well as on the age and physical condition of the fish (Taksdal et al. 1998, Bruslind \& Reno 2000, Houston et al. 2010). Additionally, survivors of IPNV infection may become sub-clinical carriers of the virus for the rest of their lives (Smail \& Munro 1985, Bootland et al. 1991, Johansen \& Sommer 1995). Aquabirnaviruses are globally distributed in the aquatic environment, and IPNV is widespread in salmonid-producing countries in Europe (Ariel \& Olesen 2002). Three species of Aquabirnavirus have been identified: IPNV is the type species of the genus, with the other 2 being Tellina virus and Yellowtail ascites virus (YTAV) (Delmas et al. 2012).

Based on their antigenic properties, aquabirnaviruses are divided into 9 serotypes within Serogroup A: A1 (reference strain West Buxton), A2 (Sp), A3 (Ab), A4 (Hecht), A5 (Tellina), A6 (Canada 1), A7 (Canada 2), A8 (Canada 3) and A9 (Jasper) (Hill \& Way 1995). Furthermore, 7 different genogroups for aquabirnaviruses (1-7) have been described, with the grouping mainly being based on the viral VP2 gene sequences (Blake et al. 2001, Nishizawa et al. 2005). The serological classification has also been shown to correlate with the genogroups: Genogroup 1 contains isolates from Serotypes A1 and A9, Genogroup 2 from Serotype A3, Genogroup 3 from Serotypes A5 and A6, Genogroup 4 from Serotypes A7 and A8, Genogroup 5 from Serotype A2, and Genogroup 6 from Serotype A4 (Blake et al. 2001). Nishizawa et al. (2005) introduced an additional Genogroup 7 composed of YTAV and aquabirnaviruses from marine fish and molluscan shellfish.

IPN was first reported in Finland in 1984 from a sea cage farm rearing rainbow trout in the southwestern coastal area (National Veterinary Institute of Finland 1985) and has occurred annually since 1987 in the coastal area of Finland for several decades without causing clinical disease or increased mortalities. The inland area of Finland has an IPN-free status according to European Council Decision 2010/221/EU. When IPN was detected at several inland farms in 2012-2013, the estimated eradication costs were enormous compared to the expected benefits, and eradication of IPNV from continental Finland was not considered feasible. Finnish authorities decided to limit the national control programme to IPN virus strains belonging to Genogroup 5, which are known to be highly pathogenic, causing mortality and clinical disease. In this article, an overview of the current ongoing epidemic is presented and the possible origin of the infections is discussed.

\section{MATERIALS AND METHODS}

\section{Origin of fish samples}

Viral samples for this study were collected from fish sent to the laboratories of the Finnish Food Safety Authority Evira for miscellaneous health screening purposes or investigation of clinical disease in 20122014. The studied fish originated from fish farms located in both the inland freshwater areas of Finland, and in the Finnish coastal area of the Baltic Sea. During 2012 and 2013, 11 IPNV-positive farms were found in the inland area of Finland previously considered free from IPNV infection. Of the IPNV-positive farms, 6 produced juvenile fish, 3 were broodfish farms, and 2 farms produced fish for human consumption. One farm had a recirculation aquaculture system (RAS), while the others employed conventional flow-through systems. All the farms used nondisinfected surface water. The positive inland farms are located above barriers to the migration of wild fish from the sea, and fish movement from the sea area to inland waters is restricted by law. The primary detection of IPNV in the inland area was carried out from samples sent to the laboratory for disease investigations (4 farms), routine risk-based surveillance (3 farms), surveillance of farms having contact with an IPNV-positive farm (2 farms) or for health screening for export (2 farms). All IPNV-positive fish were rainbow trout Oncorhynchus mykiss aged 0 or 1 yr, except for 2 detections from whitefish Coregonus lavaretus (broodfish and $0 \mathrm{yr}$ ) (see Table 1). Viral samples collected from the coastal area consisted of samples sent for routine risk-based surveillance or disease investigations and came from farms producing rainbow trout food fish. Epidemiological data were collected by municipal or provincial veterinarians or via personal surveys of the farms carried out by the authors. Data collected previously by personal communications from coastal farms were also used.

The samples consisted of whole fish on ice, live fish or ovarian fluids. The whole fish were necropsied, and pooled organ samples were taken for virus isolation by cell culture. When clinical signs of disease were noted, samples were taken for histopathology and bacteriology.

\section{Histological and immunohistochemical detection of IPN virus}

Tissue samples were collected at necropsy from fish showing macroscopic signs of disease, fixed in 
$10 \%$ neutral buffered formalin, embedded in paraffin, sectioned $(4 \mu \mathrm{m})$, stained with haematoxylin and eosin (H\&E) according to standard laboratory practice and examined by light microscopy. Formalinfixed paraffin-embedded tissues cut into $4 \mu \mathrm{m}$ sections were stained immunohistochemically using an UltraVision ONE HRP polymer detection system kit (Thermo Fisher Scientific) according to the manufacturer's instructions, after incubation with either a monoclonal antibody against VP2 protein of IPNV (Aquatic Diagnostic) at a dilution of 1:10 for $60 \mathrm{~min}$ at room temperature (RT) or a rabbit anti-IPN virus serum (provided by Professor $\varnothing$. Evensen, Norwegian School of Veterinary Science, Norway) at a dilution of 1:1000 for 60 min at RT. Slides were observed microscopically for localization of IPNV, as indicated by red/brown staining. IPNV-positive and IPNV-negative slides were included as controls.

\section{Virus isolation}

Virus isolations were carried out from pooled organ samples or ovarian fluids. Pooled brain, anterior kidney and spleen tissue or ovarian fluids from a maximum of 10 fish were homogenised in 9 volumes of cell culture medium (Eagle's MEM, Gibco plus 8 to $10 \%$ foetal bovine serum; $\mathrm{pH} 7.2$ to 7.4 ) containing penicillin and streptomycin. Homogenates were centrifuged $\left(15 \mathrm{~min}, 4000 \times g, 4^{\circ} \mathrm{C}\right)$ and the supernatants inoculated onto subconfluent monolayer cell cultures of bluegill fry (BF-2; Wolf et al. 1966) and epithelioma papulosum cyprini (EPC; Fijan et al. 1983) cultures in 24-well plates (Nunc A/S) at final dilutions of 1:100 and 1:1000. The inoculated cultures were incubated at $16^{\circ} \mathrm{C}$ (buffered with sodium carbonate $7.5 \%$, Gibco 25080) and regularly inspected microscopically for the occurrence of cytopathic effect (CPE). After $7 \mathrm{~d}$ of incubation at $16^{\circ} \mathrm{C}$, supernatant from samples without CPE was diluted 1:100 and 1:1000, sub-cultured onto fresh cells and incubated for a further $7 \mathrm{~d}$. When CPE was observed, the supernatant was collected and stored at $-70^{\circ} \mathrm{C}$ for future studies.

\section{ELISA for IHNV, IPNV, SVCV and VHSV}

Aliquots of $50 \mu \mathrm{l}$ of culture medium from cell cultures showing evidence of CPE were analysed with commercial ELISA kits according to the manufacturer's instructions to test for the presence of IPNV, SVCV, VHSV (Test-Line) and IHNV (Bio-X Diagnostics S.P.R.L.).

\section{RNA extraction}

The infected cell culture monolayers were harvested and the total RNA was extracted using the QIAamp Viral RNA Mini Kit (Qiagen) according to the manufacturer's instructions.

\section{PCR and sequencing}

Primers F (5'-ACG AAC CCC CAG GAC AA-3'; modified from McColl et al. 2009) and A2 (5'-GAC AGG ATC ATC TTG GCA TAG T-3'; Bain et al. 2008) were used to amplify $776 \mathrm{bp}$ of the IPNV VP2 gene. The 1-step RT-PCR reaction was performed using the QIAGEN OneStep RT-PCR Kit according to the manufacturer's instructions, and with $5 \mu$ l of RNA as a reaction template. PCR products were purified from agarose gel using MinElute Gel Extraction Kit (Qiagen). Both strands of the PCR products were sequenced using the Big Dye Terminator v1.1 Cycle Sequencing Kit (Applied Biosystems) and an Applied Biosystems 3130 Genetic Analyzer. The raw sequence data were analysed using Sequencing Analysis Software 5.1 (Applied Biosystems). Multiple sequence alignments of the sequence data obtained in this study and of some previously published IPNV VP2 gene sequences were performed using Clustal X version 2.1 (Larkin et al. 2007). Percent similarity values of sequence pairs were calculated using the MegAlign program from the DNASTAR Lasergene 10 application package. Maximum likelihood phylogenetic analyses were performed with MEGA version 6 (Tamura et al. 2013). Several previously published viral VP2 gene sequences were included in the analyses: the GenBank accession numbers for the sequences used were AF342735 (Jasper), AF343572 (VR299), AF342729 (Ab), AY780919 (6B1A), AF342732 (Canada 1), AF342731 (Tellina virus 2), AF342733 (Canada 2), AF342734 (Canada 3), AJ622822 (Sp 3175), AJ489229 (88R), AF342730 (He), AY283781 (Y-6) and AY283783 (H1).

\section{RESULTS}

\section{Clinical signs, gross pathology and histopathology}

Elevated mortalities were reported in 10 out of 35 IPNV-positive fish groups, varying from less than 1 to up to $40 \%$. When mortalities exceeded $10 \%$, concurrent bacterial infections (Flavobacterium psychrophilum and $F$. columnare) were always detected 
Table 1. Infectious pancreatic necrosis virus (IPNV) Genogroup 2 findings in Finnish inland farms 2012-2014. Table shows farm ID and location (Areas A-D: water catchment area/river basin), sampling date, no. of pooled samples per fish group, no. of fish per pooled sample, no. of virus isolation positive pools, clinical signs, the occurrence of histopathological changes, increased mortality, weight and age of fish, water temperature (if known) and other concomitant infections observed. Sample material consists of organs if not mentioned otherwise. nk: not known; nd: histology or bacteriology not done; inc.: inconclusive (severe autolysis)

\begin{tabular}{|c|c|c|c|c|c|c|c|c|c|c|}
\hline $\begin{array}{l}\text { Farm } \\
\text { ID }\end{array}$ & $\begin{array}{c}\text { Date } \\
\text { (d.mo.yr) }\end{array}$ & $\begin{array}{l}\text { No. pooled } \\
\text { samples }\end{array}$ & $\begin{array}{l}\text { No. fish } \\
\text { per pool }\end{array}$ & $\begin{array}{l}\text { No. of po- } \\
\text { sitive pools }\end{array}$ & $\begin{array}{l}\text { Clinical } \\
\text { signs }\end{array}$ & $\begin{array}{l}\text { Histopath. } \\
\text { changes }\end{array}$ & $\begin{array}{c}\text { Mortality } \\
(\%)\end{array}$ & $\begin{array}{l}\text { Fish wt }(\mathrm{g}) / \\
\text { age }(\mathrm{yr})\end{array}$ & $\begin{array}{l}\text { Water } \\
\text { temp. }\left({ }^{\circ} \mathrm{C}\right)\end{array}$ & Other infections \\
\hline 1B & 29.2 .2012 & 3 & 10 & 3 & Yes & Yes & $1-2$ & $8 / 0$ & 16 & $\begin{array}{l}\text { Flavobacterium } \\
\text { psychrophilum }\end{array}$ \\
\hline 1B & 16.3.2012 & 12 & 5 & 8 & $\mathrm{nk}$ & Yes & $1-2$ & $\mathrm{nk} / 0$ & $\mathrm{nk}$ & Bacteriology nd \\
\hline $1 \mathrm{~B}$ & 16.3.2012 & 3 & 10 & 3 & nk & Yes & $1-2$ & $\mathrm{nk} / 0+$ & nk & Bacteriology nd \\
\hline 1B & 13.5 .2014 & 2 & 10 & 1 & Yes & Yes & $\mathrm{nk}$ & $\mathrm{nk} / 0$ & $15-19$ & No \\
\hline 1B & 15.7 .2014 & 4 & 10 & 2 & Yes & Yes & $0-2$ & $\mathrm{nk} / 0$ & 16 & No \\
\hline $2 \mathrm{~B}$ & 16.3.2012 & 12 & 5 & 3 & nk & nd & $1-2$ & $\mathrm{nk} / 0+$ & $\mathrm{nk}$ & F. psychrophilum \\
\hline $2 \mathrm{~B}$ & 28.8 .2012 & 1 & 10 & 1 & $\mathrm{nk}$ & nd & $\mathrm{nk}$ & $6 / 0$ & $\mathrm{nk}$ & F. columnare \\
\hline $2 \mathrm{~B}$ & 25.6 .2013 & 1 & 10 & 1 & Yes & Yes & $\mathrm{nk}$ & $3 / 0$ & 19 & No \\
\hline $2 \mathrm{~B}$ & 16.7 .2013 & 2 & 9,6 & 2 & Yes & Yes & 12 & $\mathrm{nk} / 0$ & 19 & F. columnare \\
\hline 2B & 4.11 .2013 & 6 & 10 & 3 & No & nd & $\mathrm{nk}$ & $30-70 / 0+$ & 3 & Bacteriology nd \\
\hline $2 \mathrm{~B}$ & 4.11 .2013 & 6 & 10 & 6 & No & nd & $\mathrm{nk}$ & $15-40 / 0+$ & 3 & Bacteriology nd \\
\hline $2 \mathrm{~B}$ & 5.11 .2013 & 6 & 10 & 1 & No & nd & $\mathrm{nk}$ & 60/0+ & 4 & Bacteriology nd \\
\hline $2 \mathrm{~B}$ & 5.11 .2013 & 6 & 10 & 3 & No & nd & $\mathrm{nk}$ & $60 / 0+$ & 4 & Bacteriology nd \\
\hline $2 \mathrm{~B}$ & 13.3.2014 & 30 & 2 & $0^{\mathrm{a}}$ & No & nd & $\mathrm{nk}$ & nk/broodfish ${ }^{\mathrm{b}}$ & nk & Bacteriology nd \\
\hline 2B & 15.7 .2014 & 2 & 10 & 2 & nk & nd & $\mathrm{nk}$ & $16-26 / 0$ & 22 & $\begin{array}{l}\text { F. columnare, } \\
\text { F. psychrophilum }\end{array}$ \\
\hline $3 \mathrm{~A}$ & 11.7 .2012 & 1 & 10 & 1 & $\mathrm{nk}$ & Yes & $\mathrm{nk}$ & $1 / 0$ & $\mathrm{nk}$ & No \\
\hline $3 \mathrm{~A}$ & 25.7 .2012 & 12 & 5 & 4 & $\mathrm{nk}$ & nd & $\mathrm{nk}$ & $25 / 0$ & $\mathrm{nk}$ & Bacteriology nd \\
\hline $3 \mathrm{~A}$ & 25.7 .2012 & 24 & 10 & 19 & $\mathrm{nk}$ & nd & $\mathrm{nk}$ & $\mathrm{nk} / 0$ & $\mathrm{nk}$ & Bacteriology nd \\
\hline $3 \mathrm{~A}$ & 6.8 .2013 & 1 & 10 & 1 & Yes & Yes & $\mathrm{nk}$ & $\mathrm{nk} / 0$ & 21 & No \\
\hline $4 \mathrm{~A}$ & 16.7.2012 & 6 & 10 & 2 & nk & nd & $\mathrm{nk}$ & $260 / 1$ & $\mathrm{nk}$ & No \\
\hline $4 \mathrm{~A}$ & 26.7 .2012 & 12 & 5 & 3 & $\mathrm{nk}$ & nd & $\mathrm{nk}$ & $130 / 1$ & $\mathrm{nk}$ & Bacteriology nd \\
\hline $4 \mathrm{~A}$ & 25.6 .2013 & 1 & 10 & 1 & nk & Yes & $\mathrm{Yes}^{\mathrm{c}}$ & $17 / 0$ & 17 & No \\
\hline $4 \mathrm{~A}$ & 4.7 .2013 & 1 & 10 & 1 & $\mathrm{nk}$ & Yes & $\mathrm{nk}$ & $45 / 1$ & 21 & F. columnare \\
\hline $4 \mathrm{~A}$ & 6.8 .2013 & 1 & 10 & 1 & $\mathrm{nk}$ & nd & $\mathrm{nk}$ & $16 / 0$ & 22 & Bacteriology nd \\
\hline $5 \mathrm{~A}$ & 25.7 .2012 & 6 & 5 & 1 & $\mathrm{nk}$ & Inc. & $\mathrm{nk}$ & $\mathrm{nk} / 1$ & $\mathrm{nk}$ & Bacteriology nd \\
\hline $6 \mathrm{C}$ & 28.8.2012 & 3 & 10 & 2 & $\mathrm{nk}$ & nd & $\mathrm{nk}$ & $\mathrm{nk} / 0+$ & $\mathrm{nk}$ & Bacteriology nd \\
\hline $6 \mathrm{C}$ & 22.8 .2013 & 6 & 10 & 3 & $\mathrm{nk}$ & nd & $\mathrm{nk}$ & $\mathrm{nk} / 0+$ & $\mathrm{nk}$ & $\begin{array}{l}\text { F. columnare, } \\
\text { F. psychrophilum }\end{array}$ \\
\hline $6 \mathrm{C}$ & 24.4 .2014 & 6 & 10 & 1 & $\mathrm{nk}$ & nd & $\mathrm{nk}$ & $\mathrm{nk} / 1$ & $\mathrm{nk}$ & Bacteriology nd \\
\hline $6 \mathrm{C}$ & 16.9.2014 & 3 & 10 & 2 & No & nd & $\mathrm{nk}$ & $\mathrm{nk} / 0+$ & $\mathrm{nk}$ & Bacteriology nd \\
\hline $7 \mathrm{~A}$ & 19.6.2013 & 1 & 5 & 1 & Yes & Yes & $<0.01$ & $2-5 / 0$ & $17-18$ & No \\
\hline $8 \mathrm{C}$ & 1.10 .2013 & 6 & 10 & 1 & $\mathrm{nk}$ & nd & nk & $\mathrm{nk} / 1+$ & nk & Bacteriology nd \\
\hline 9B & 13.8.2014 & 1 & 10 & 1 & Yes & Yes & $0-40$ & $4 / 0$ & 19 & $\begin{array}{l}\text { F. columnare, } \\
\text { protozoan infection }\end{array}$ \\
\hline 9B & 13.8.2014 & 1 & 10 & 1 & Yes & No & $<2$ & $7 / 0^{\mathrm{d}}$ & 19 & $\begin{array}{l}\text { F. columnare, ciliate } \\
\text { infection }\end{array}$ \\
\hline 10D & 19.11 .2014 & 3 & 10 & 1 & No & nd & $\mathrm{nk}$ & nk/broodfish ${ }^{\mathrm{d}, \mathrm{e}}$ & 7 & Bacteriology nd \\
\hline $11 \mathrm{~A}$ & 17.12 .2014 & 3 & 10 & 2 & $\mathrm{nk}$ & nd & $\mathrm{nk}$ & $\mathrm{nk} / 1+$ & nk & Bacteriology nd \\
\hline
\end{tabular}

(Table 1). Clinical signs were noted in 9 fish groups and consisted of mild to moderate signs, including a lack of appetite, aberrant swimming behaviour, abdominal distension and exophthalmia (Table 1). Clinical signs were seen in both rainbow trout and whitefish in the smaller 0 yr age group, generally in first-feeding fish. Macroscopic lesions consisted of petechial bleeding in the peripancreatic fat around the pyloric caeca and dark coloration of the skin. Histopathological findings were only seen in rainbow trout and consisted of mild to severe necrotic pancreatitis appearing as coagulative necrosis in the exocrine pancreatic acinar cells (Fig. 1A). Endocrine pancreatic tissue and peripancreatic fatty tissue were mainly intact. A varying degree of necrosis of the intestinal mucosa in pyloric caeca with intra-luminal inflammatory exudates including McKnight cells, i.e. apoptotic mucosal epithelial cells, was noted. Liver changes were observed in some cases consisting of moderate to severe haemorrhages in liver parenchyma and mild fo- 


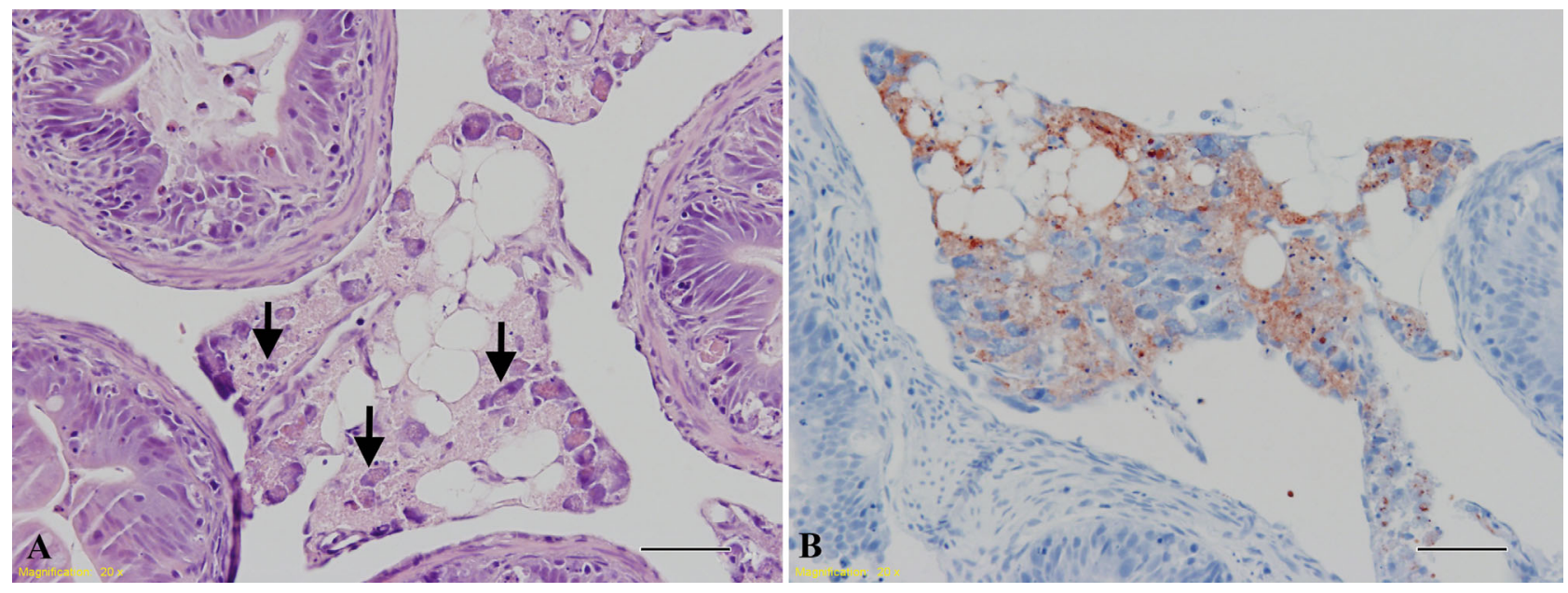

Fig. 1. Pyloric caeca and pancreatic tissue of rainbow trout fry infected with infectious pancreatic necrosis virus (IPNV). (A) Severe necrotic pancreatitis. Arrows indicate necrotic pancreatic acinar cells. H\&E. (B) Immunohistochemical staining showing IPNV-positive exocrine pancreatic acinar cells (brownish red colour). Scale bars $=50 \mu \mathrm{m}$

cal necrosis. In one case, histopathological changes in the pyloric region were noted in $1 \mathrm{yr}$ old fish.

Immunohistochemical staining was performed on selected samples with microscopic lesions suggestive of IPN. A positive immunohistochemical staining reaction was observed in affected exocrine pancreatic tissue (Fig. 1B) and liver tissue. Clinical signs were observed at water temperatures varying between 15 and $21^{\circ} \mathrm{C}$, and histopathological changes were detected in fish reared at water temperatures of up to $21^{\circ} \mathrm{C}$ (Table 1).

\section{Virus isolation and identification}

IPNV was isolated in cell culture from 88 out of 194 pooled samples investigated. Virus isolation was also successful from samples collected at temperatures above $14^{\circ} \mathrm{C}$, which is the upper temperature limit in routine risk-based surveillance for fish viruses (European Commission 2001). In one case, one cell culture negative sample was detected as PCR-positive from pooled organs (Table 1). In this single case, both virus isolation and RT-PCR were used in order to verify the disease status of broodfish. Regarding the rest of the samples studied, isolates were initially identified as IPNV by the typical cytopathic effect always associated with IPNV-infected cell cultures of BF-2 and, occasionally, EPC cell lines. The isolated viruses were identified as IPNV by ELISA and RT-PCR. The samples were negative for IHNV, spring viraemia of carp virus (SVCV) and viral haemorrhagic septicaemia virus (VHSV) by ELISA.

\section{Sequence analyses}

Altogether, 85 IPNV isolates were sequenced and analysed based on the partial viral capsid protein (VP2) gene region. Among the isolates studied, 29 unique VP2 sequence types were detected (Table 2), of which 23 belonged to IPNV Genogroup 2, and 6 to Genogroup 5 based on phylogenetic analyses and sequence pair similarity values (Fig. 2, Table 3). Genogroup 5 isolates were only found at the coastal fish farms, whereas Genogroup 2 isolates were detected at both the inland and coastal farms. The overall sequence pair similarity among the Finnish Genogroup 2 isolates (FI-2) varied between 97.6 and $99.9 \%$ for nucleotide sequences (737 bp) and between 96.7 and $100 \%$ for amino acid sequences (245 aa). Among the Genogroup 5 isolates (FI-5), the similarity values for nucleotide sequences were 98.2 to $99.9 \%$ and for amino acid sequences 98.0 to $100 \%$. All isolates studied, except for sequence types FI-217 and FI-2-23, had an amino acid pattern associated with low virulence in the VP2 gene: proline at residue 217 and threonine at residue 221 (Santi et al. 2004, Song et al. 2005). Sequence types FI-2-17 and FI-2-23 had serine in position 217 and threonine in position 221. The first IPNV isolate (VP2 sequence type FI-2-1) found in the inland area in 2012 was similar to the isolate already detected at one of the coastal farms in 2011 (Farm ID 1S, Table 2). Subsequently, in 2012, 2013 and 2014, the sequence type FI-2-1 was detected at several other inland and coastal farms. On some of the farms (Farm ID 21S, 1B, 2B, 7A, 3S and 22S, Table 2), 2 different VP2 sequence types were detected during the same year. 
Table 2. VP2 sequence types of the studied infectious pancreatic necrosis virus (IPNV) isolates. Farm areas A-D are inland; $\mathrm{S}$ is coast

\begin{tabular}{|c|c|c|c|c|}
\hline $\begin{array}{l}\text { Sequence } \\
\text { type }\end{array}$ & $\begin{array}{l}\text { Farm } \\
\text { ID }\end{array}$ & $\begin{array}{c}\text { Year of } \\
\text { isolation }\end{array}$ & $\begin{array}{l}\text { Sample } \\
\text { ID }\end{array}$ & $\begin{array}{l}\text { GenBank } \\
\text { acc. no. }\end{array}$ \\
\hline \multirow[t]{20}{*}{ FI-2-1 } & $1 \mathrm{~S}$ & 2011 & 1014 & \multirow[t]{20}{*}{ KR780984 } \\
\hline & & 2012 & 617 & \\
\hline & 1B & 2012 & $89-91,107,133$ & \\
\hline & $3 \mathrm{~A}$ & 2012 & $\begin{array}{c}695,723,735 \\
747,758\end{array}$ & \\
\hline & & 2013 & 401 & \\
\hline & \multirow[t]{2}{*}{$4 \mathrm{~A}$} & 2012 & $696-698,798$ & \\
\hline & & 2013 & 339, 362, 399 & \\
\hline & $5 \mathrm{~A}$ & 2012 & 712 & \\
\hline & $2 \mathrm{~S}$ & 2012 & 1521 & \\
\hline & $7 \mathrm{~A}$ & 2013 & 331 & \\
\hline & $3 \mathrm{~S}$ & 2013 & 392 & \\
\hline & \multirow[t]{2}{*}{$6 \mathrm{C}$} & 2013 & 435,437 & \\
\hline & & 2014 & 184,558 & \\
\hline & $4 \mathrm{~S}$ & 2013 & 670 & \\
\hline & $2 \mathrm{~S}$ & 2013 & 753 & \\
\hline & $5 \mathrm{~S}$ & 2013 & 789 & \\
\hline & $6 \mathrm{~S}$ & 2013 & 857 & \\
\hline & $7 \mathrm{~S}$ & 2014 & 768 & \\
\hline & $8 \mathrm{~S}$ & 2014 & 958 & \\
\hline & $9 \mathrm{~S}$ & 2014 & 969 & \\
\hline \multirow[t]{7}{*}{ FI-2-2 } & $2 \mathrm{~B}$ & 2012 & 893 & \multirow[t]{7}{*}{ KR780985 } \\
\hline & & 2013 & $369,370,722$ & \\
\hline & & & $726,729,732$ & \\
\hline & & & $766,771,772$ & \\
\hline & & 2014 & 405,406 & \\
\hline & $7 \mathrm{~A}$ & 2013 & 338 & \\
\hline & $10 \mathrm{~S}$ & 2013 & 750 & \\
\hline \multirow[t]{3}{*}{ FI-2-3 } & $6 \mathrm{C}$ & 2012 & 890 & \multirow[t]{3}{*}{ KR780986 } \\
\hline & $8 \mathrm{C}$ & 2013 & 520 & \\
\hline & $10 \mathrm{~S}$ & 2013 & 883 & \\
\hline FI-2-4 & 2B & 2012 & 124 & KR780987 \\
\hline FI-2-5 & $3 \mathrm{~A}$ & 2013 & 745 & KR780988 \\
\hline FI-2-6 & $11 \mathrm{~S}$ & 2013 & 391 & KR780989 \\
\hline FI-2-7 & $6 \mathrm{C}$ & 2013 & 433 & KR780990 \\
\hline FI-2-8 & $12 \mathrm{~S}$ & 2013 & 530 & KR780991 \\
\hline FI-2-9 & $2 \mathrm{~B}$ & 2013 & 767 & KR780992 \\
\hline FI-2-10 & $2 \mathrm{~B}$ & 2014 & 103 & KR780993 \\
\hline FI-2-11 & 1B & 2014 & $251,399,401$ & KR780994 \\
\hline \multirow[t]{2}{*}{ FI-2-12 } & 9B & 2014 & $459,460,486$ & KR780995 \\
\hline & $12 \mathrm{~S}$ & 2014 & 516 & \\
\hline FI-2-13 & $10 \mathrm{D}$ & 2014 & 940 & KR780996 \\
\hline FI-2-14 & $11 \mathrm{~A}$ & 2014 & 1005 & KR780997 \\
\hline FI-2-15 & $2 \mathrm{~S}$ & 2011 & 1049 & KR780998 \\
\hline FI-2-16 & $13 \mathrm{~S}$ & 2012 & 568 & KR780999 \\
\hline FI-2-17 & $11 \mathrm{~S}$ & 2012 & 844 & KR781000 \\
\hline \multirow[t]{2}{*}{ FI-2-18 } & $15 \mathrm{~S}$ & 2013 & 692 & KR781001 \\
\hline & $16 \mathrm{~S}$ & 2013 & 740 & \\
\hline FI-2-19 & $17 \mathrm{~S}$ & 2013 & 735 & KR781002 \\
\hline FI-2-20 & $18 \mathrm{~S}$ & 2014 & 764 & KR781003 \\
\hline FI-2-21 & $19 \mathrm{~S}$ & 2014 & 954 & KR781004 \\
\hline FI-2-22 & $1 \mathrm{~S}$ & 2014 & 978 & KR781005 \\
\hline FI-2-23 & $20 \mathrm{~S}$ & 2014 & 1038 & KR781006 \\
\hline FI-5-24 & $21 \mathrm{~S}$ & 2012 & 639 & KR781007 \\
\hline FI-5-25 & $21 \mathrm{~S}$ & 2012 & 640 & KR781008 \\
\hline FI-5-26 & $22 \mathrm{~S}$ & 2012 & 666 & KR781009 \\
\hline FI-5-27 & $22 \mathrm{~S}$ & 2012 & 1496 & KR781010 \\
\hline FI-5-28 & $23 \mathrm{~S}$ & 2012 & 1613 & KR781011 \\
\hline FI-5-29 & $24 \mathrm{~S}$ & 2013 & 798,799 & KR781012 \\
\hline
\end{tabular}

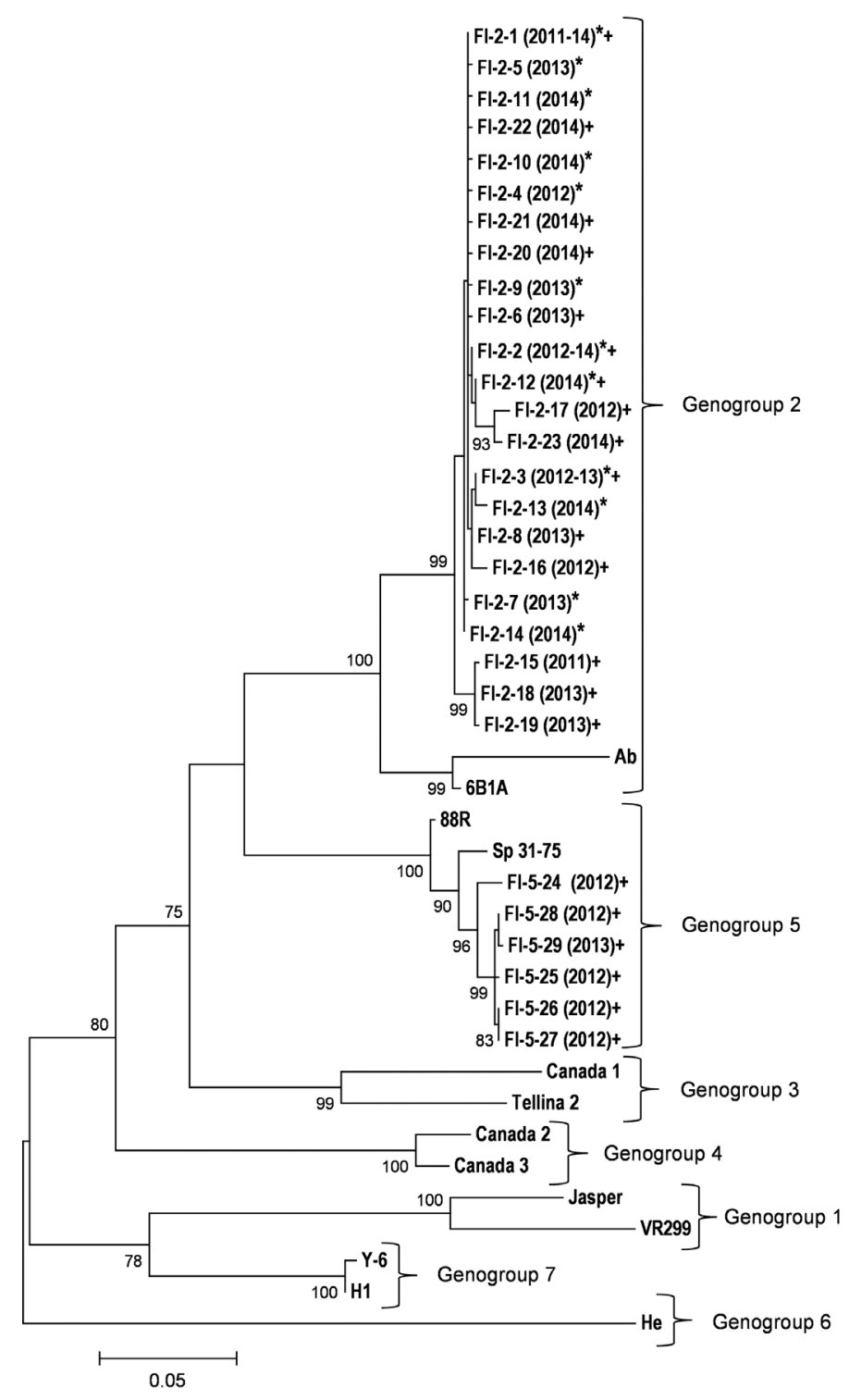

Fig. 2. Maximum likelihood analysis based on partial viral VP2 protein gene sequences. The year of isolation for the Finnish infectious pancreatic necrosis virus (IPNV) isolates (FI) is given in parentheses. The GenBank numbers for the previously published sequences are Jasper (AF342735), VR299 (AF343572), Ab (AF342729), 6B1A (AY780919), Canada 1 (AF342732), Tellina virus 2 (AF342731), Canada 2 (AF342733), Canada 3 (AF342734), Sp 31-75 (AJ622822), 88R (AJ489229), He (AF342730), Y-6 (AY283781) and H1 (AY283783). Numbers at the nodes of the tree indicate bootstrap values of 1000 replicates; values under 70 not shown. Scale bar indicates 0.05 nucleotide substitutions per site. Genogroups indicated with curly brackets. *: inland isolates; +: coastal isolates; ${ }^{*}+$ : inland and coastal isolates

Representative VP2 gene sequences were submitted to the NCBI GenBank with the corresponding accession numbers as listed in Table 2 
Table 3. Infectious pancreatic necrosis virus (IPNV) sequence pair similarity values (\%) based on the nucleotide (737 bp) and amino acid (245 aa) sequences of the partial VP2 gene. Nucleotide sequence similarity values are presented in the upper right and amino acid values in the lower left. All Finnish IPNV isolates from this study were included in the calculations of similarity values. For each Finnish IPNV genogroup (FI-2 = Finnish Genogroup 2 isolates, FI-5 = Finnish Genogroup 5 isolates) a range of values is given. The highest similarity values for FI-2 and FI-5 are given in bold. The GenBank accession numbers for the previously published sequences are AF342735 (Jasper), AY780919 (6B1A), AF342731 (Tellina virus 2), AF342733 (Canada 2), AJ622822 (Sp 31-75), AF342730 (He) and AY283781 (Y-6). Genogroups for the previously published sequences are given in parentheses

\begin{tabular}{|lccccccccc|}
\hline & FI-2 & FI-5 & Jasper & 6B1A & Tellina 2 & Canada 2 & Sp 31-75 & He & Y-6 \\
& & & $(1)$ & $(2)$ & $(3)$ & $(4)$ & $(5)$ & $(6)$ \\
\hline FI-2 & - & $85.5-86.4$ & $77.7-78.2$ & $\mathbf{9 3 . 8 - 9 4 . 4}$ & $84.7-85.2$ & $81.3-82.0$ & $86.8-87.5$ & $72.3-73.5$ & $79.9-80.3$ \\
FI-5 & $87.3-89.0$ & - & $79.0-79.1$ & $85.8-86.3$ & $82.5-83.0$ & $81.4-82.0$ & $\mathbf{9 7 . 4 - 9 7 . 6}$ & $75.3-75.8$ & $81.7-81.8$ \\
Jasper (1) & $83.7-84.1$ & $84.1-84.5$ & - & 77.3 & 76.4 & 77.5 & 79.2 & 72.9 & 81.1 \\
6B1A (2) & $\mathbf{9 6 . 7 - 9 8 . 0}$ & $89.4-89.8$ & 84.9 & - & 84.7 & 81.3 & 86.3 & 73.3 & 80.1 \\
Tellina 2 (3) & $89.0-90.2$ & $85.7-86.5$ & 84.5 & 89.0 & - & 79.8 & 83.4 & 73.5 & 81.5 \\
Canada 2 (4) & $83.7-84.1$ & $84.9-85.7$ & 84.5 & 84.9 & 84.1 & - & 82.4 & 74.2 & 79.5 \\
Sp 31-75 (5) & $89.4-90.6$ & $\mathbf{9 7 . 1 - 9 7 . 6}$ & 84.5 & 91.4 & 87.8 & 86.5 & - & 75.8 & 82.8 \\
He (6) & $79.2-80.4$ & $83.3-83.7$ & 79.2 & 80.8 & 79.2 & 79.6 & 84.5 & - & 74.6 \\
Y-6 (7) & $87.3-88.2$ & $86.1-86.9$ & 86.5 & 88.2 & 89.4 & 84.1 & 87.8 & 80.0 & - \\
\hline
\end{tabular}

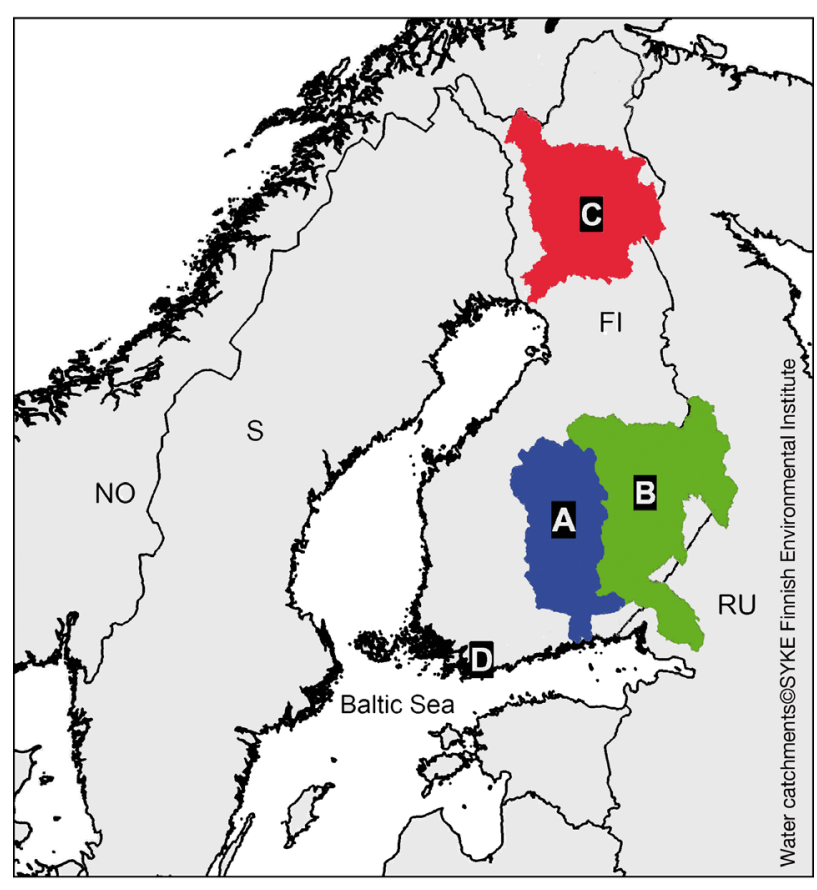

Fig. 3. Geographical location (main water catchment areas) of farms positive for infectious pancreatic necrosis virus (IPNV) Genogroup 2 in continental Finland. A: Kymijoki water catchment area; B: Vuoksi water catchment area; C: Kemijoki water catchment area; D: Gulf of Finland, coastal zone (enclosed freshwater bay). Country names: NO, Norway; S, Sweden; FI, Finland; RU, Russia

\section{Epidemiology and geographical location of positive farms}

The location of the main water catchment areas of the inland farms positive for IPNV Genogroup 2 is indicated in Fig. 3. These farms are located in 3 main water catchment areas (Areas A-C in Fig. 3) and in 1 area located coastally but separated from the coast by a restriction on fish movement from the sea to freshwater by a physical barrier (Area D in Fig. 3). The majority of the positive farms belong to 2 separate owners, and based on epidemiological investigations, no connections, including the movement of fish, exist between these 2 businesses. Two individual IPNV-positive farms with no apparent connection to other IPNV-positive farms were also detected. Epidemiological investigations could not determine an infection route from the sea area to the affected farms in the inland areas. There has been annual live fish transportation from the water catchment areas A and $\mathrm{B}$ to the brackish water area in the Baltic Sea, but not vice versa. Transport vehicles undergo disinfection after each transportation of fish to brackish water at specific washing locations. Area D is located very close to the brackish water area but lacks direct water contact. Live fish movement from Area B to D has occurred but not directly from IPNV-positive fish groups.

\section{DISCUSSION}

Finnish fish production is roughly divided into brood fish and fry production in the inland area and food fish production in the sea area. Fish transfer from the brackish water sea area to the inland area is restricted by legislation. The Finnish inland area was IPN-free until 2012 and is still free of IPNV Genogroup 5 viruses. There are around 240 farms rearing IPN susceptible species, of which around approximately 140 are located in inland waters. Between 
2000 and 2010, an average of ca. 150 farms per year were tested for IPN. During this period, the number of positive farms from which IPNV was isolated varied from 1 to 9 annually, with all of these being located in the sea area. IPNV isolations from the sea area have generally occurred from adult fish with no clinical signs of disease in connection with the surveillance of viral diseases. A few isolations at sea have been carried out in association with bacterial pathogens causing clinical disease.

In Europe, most IPN outbreaks reported in salmonids have been due to infection with IPNV isolates of Genogroup 5 (Serotype Sp) (Melbye \& Christie 1994, Bain et al. 2008, Ruane et al. 2009). Moreover, Genogroup 5 isolates have been shown to be more virulent in rainbow trout than Genogroup 2 (Serotype Ab) isolates (Novoa et al. 1995). Here, all the inland isolates studied belonged to Genogroup 2, whereas IPNV isolations from the sea area consisted of both Genogroups 2 and 5. Three sequence types (FI-2-1, FI2-2-2 and FI-2-3) of Genogroup 2 isolations from the sea area were similar to prior isolations from the inland area, reflecting the practice of moving juvenile fish from the inland area to the sea area for further rearing. One finding of Genogroup 2 sequence type FI-2-1 in the sea area in 2011 prior to the inland findings provides strong support for the assumption that the infection of inland farms originates from the sea area, although this has not yet been verified.

IPN is generally considered a coldwater disease, with clinical disease and increased mortality peaking at $10^{\circ} \mathrm{C}$ and decreasing at $15^{\circ} \mathrm{C}$ (Frantsi \& Savan 1971, Lapierre et al. 1986, Okamoto et al. 1987). In Finland, IPNV infection was encountered at water temperatures as high as $22^{\circ} \mathrm{C}$, which is much higher than generally cited in the literature. Clinical signs of disease and histopathological changes typical of IPN were also seen at water temperatures as high as $21^{\circ} \mathrm{C}$. Whether this is connected with the specific strains of virus is yet to be shown. The change in the temperature range of the virus causing clinical disease is of importance with regard to economic consequences, as it lengthens the susceptible time period for the disease. This is especially true if the overall virulence of the present Genotype 2 viruses were to increase. A possible way to minimise economic losses due to clinical disease is to avoid rearing susceptible age groups during the warm water period.

Because routine risk-based viral sampling is conducted at water temperatures below $14^{\circ} \mathrm{C}$, the prior, non-detected presence of a low pathogenic IPNV in the inland area is a possibility. The fact that disease investigations during the warm-water period usu- ally do not include viral sampling supports this. However, histopathological investigations would have revealed an ongoing clinical infection, and lesions typical of IPN had not been detected before the present epidemic.

The pathogenicity of IPNV isolates has repeatedly been associated with certain VP2 amino acids (Bruslind \& Reno 2000, Santi et al. 2004, Shivappa et al. 2004, Song et al. 2005). In the present study, isolates from both Genogroups 2 and 5 exhibited a low to nonvirulent VP2 amino acid pattern at positions 217 and 221, which corresponds with the mild clinical signs detected at Finnish farms. Histopathological changes typical for IPN were observed; however, the recorded mortalities were generally low. Several factors affecting pathogenicity have been recorded, including environmental stress (Taksdal et al. 1998), the strain of virus (Song et al. 2005) and an inherited factor in host immunity (Ozaki et al. 2001). It has been shown that a low pathogenic Genogroup 5 IPNV strain can demonstrate pathogenicity in persistently infected Atlantic salmon subjected to stress (Gadan et al. 2013). Even though similar studies have not been performed with Genogroup 2 IPNV isolates, the recent introduction and rapid spread of Genogroup 2 IPNV in Finnish inland farms might be a cause of future disease outbreaks and pose a possible threat to the fish farming industry.

The reason for the present spread of IPNV Genogroup 2 within a short period of time into 3 different inland water catchment areas is still to be explained. In general, IPN outbreaks can be a result of vertical transmission, poor biosecurity in the production system or contaminated water supplies. No direct infection routes have been established by epidemiological investigations, except for the 2 farms directly linked with a positive farm through live fish transfers. The farms have used roe from domestic and previously IPN-free broodfish, and no imports have occurred. The possibility of an infection carried by wild fish cannot be ruled out, since all affected farms are directly connected with surface waters; however, the infection occurred in 3 separate water catchment areas within a short time frame. No systematic, targeted surveys on the occurrence of IPNV in wild fish in Finnish waters have been carried out. However, wild salmonid broodfish and other wild salmonids sent to Evira are tested yearly for IPN, both from the sea area and the inland area, and no IPNV has been found in inland waters. In Norway, where IPNV is widely spread in cultured salmon, only a few infections have been found in migrating wild salmonids, suggesting that the spread of the virus is determined 
more by the size, density, movement and management of the host populations than the virus itself (Brun 2003, Garseth \& Biering 2015). Although epidemiological investigations could not identify an infection route, the most probable causes for the spread of the disease include vehicles for transporting live fish and feed, vaccination equipment and the movement of people between farms.

The initial isolation was carried out from fish farmed in a RAS. Due to the nature of this rearing system, possible stressors such as a high fish density or suboptimal water quality parameters may reduce the fish immune defence, thus increasing susceptibility to disease (Noble \& Summerfelt 1996). Furthermore, due to the reuse of circulating water, the pathogen load may increase more rapidly in this type of system compared to flow-through systems.

Attempts to eradicate the disease were made at Farm 3A. The measures for eradication consisted of destruction of fish, thorough mechanical cleaning and disinfection of tanks and equipment followed by fallowing for $1 \mathrm{mo}$. However, the virus was found again the following year, and the eradication attempt had thus failed. Four out of 5 farms initially infected in 2012 were positive even in 2013, showing the persistent nature of the virus. The possibility of IPNV-positive wild fish in the proximity of the virus-positive farms has to be considered when evaluating the management of the infection, as all affected farms use surface water or have cages directly placed in lakes. At farms with cages in lakes, no eradication measures could be taken into consideration, and the possibility of virus-positive wild fish in this area can be considered high. Further attempts to eradicate IPNV Genogroup 2 infections in the inland waters of Finland were not made due to the persistence of the virus, the possibility of IPNV-positive wild fish and use of surface water, as well as the large size of the affected farms and the obscurity of the initial infection route of the virus. The legislative disease control of IPN in Finnish inland waters is now limited to Genogroup 5, as the potentially more virulent IPNV Genogroup 5 exists endemically in Finnish coastal waters, with the inland area remaining free. The most important means of preventing the spread of this genogroup to inland waters is the restriction of fish and egg transfer from areas not known to be free of IPNV Genogroup 5. Effective health control of brood fish stocks is also essential. Further studies on the pathogenicity of Finnish IPNV Genogroups 2 and 5 are also warranted to evaluate the need for control of IPN in the inland waters of Finland.
Acknowledgements. The authors thank the Finnish Foundation of Veterinary Research for financial support. The staff at the Research and Laboratory Department of Evira, especially Hanna Kauno, Katri Leino and Katri Vainio-Suikola, are also greatly appreciated for their contribution.

\section{LITERATURE CITED}

Ariel E, Olesen NJ (2002) Finfish in aquaculture and their diseases - a retrospective view on the European Community. Bull Eur Assoc Fish Pathol 22:72-85

Bain N, Grecory A, Raynard RS (2008) Genetic analysis of infectious pancreatic necrosis virus from Scotland. J Fish Dis 31:37-47

Blake S, Ma JY, Caporale DA, Jairath S, Nicholson BL (2001) Phylogenetic relationships of aquatic birnaviruses based on deduced amino acid sequences of genome segment $\mathrm{A}$ cDNA. Dis Aquat Org 45:89-102

> Bootland LM, Dobos P, Stevenson RMW (1991) The IPNV carrier state and demonstration of vertical transmission in experimentally infected brook trout. Dis Aquat Org 10: 13-21

Brun E (2003) Epidemiology. In: Skjelstad B, Brun E, Jensen I, Johansen LH and others (eds) IPN in salmonids-a review. VESO and FHL, Trondheim, p 51-67

Bruslind LD, Reno PW (2000) Virulence comparison of three Buhl-subtype isolates of infectious pancreatic necrosis viruses ion brook trout fry. J Aquat Anim Health 12: 301-315

Delmas B, Mundt E, Vakharia VN, Wu JL (2012) Family Birnaviridae. In: King AMQ, Adams MJ, Carstens EB, Lefkowitz EJ (eds) Virus taxonomy: classification and nomenclature of viruses: Ninth Report of the International Committee on Taxonomy of Viruses. Elsevier Academic Press, San Diego, CA, p 499-507

$>$ Dobos P (1995) Protein-primed RNA Synthesis in vitro by the virion-associated RNA polymerase of infectious pancreatic necrosis virus. Virology 208:19-25

European Commission (2001) European Commission Decision 2001/183/EC of 22 February 2001 laying down the sampling plans and diagnostic methods for the detection and confirmation of certain fish diseases and repealing Decision 92/532/EEC. Off J Euro Commun L 067:00650076

Fijan N, Sulimanovic D, Bearzotti M, Muzinic D and others (1983) Some properties of the Epithelioma papulosum cyprini (EPC) cell line from carp (Cyprinus carpio). Ann Inst Pasteur Virol 134:207-220

Frantsi C, Savan M (1971) Infectious pancreatic necrosis virus - temperature and age factors in mortality. J Wildl Dis 7:249-255

> Gadan K, Sandtrø A, Marjara IS, Santi N, Munang'andu HM, Evensen $\varnothing$ (2013) Stress-induced reversion to virulence of infectious pancreatic necrosis virus in naïve fry of Atlantic salmon (Salmo salar L.). PLoS ONE 8: e54656

Garseth Å, Biering E (2015) Health monitoring of wild anadromous salmonids in fresh water in Norway. In: Garseth $\AA$, Madhun AS, Biering E, Isachsen CH and others (eds) Annual report 2014: annual report on health monitoring of wild anadromous salmonids in Norway. Institute of Marine Research No. 7-2015 and Norwegian Veterinary Institute No. 10-2015. Institute of Marine Research and Norwegian Veterinary Institute, p 1-14 
Hill BJ (1982) Infectious pancreatic necrosis virus and its virulence. In: Roberts R (ed) Microbial diseases of fish. Blackwell, London, p 91-114

Hill BJ, Way K (1995) Serological classification of infectious pancreatic necrosis (IPN) virus and other aquabirnaviruses. Annu Rev Fish Dis 5:55-77

Houston RD, Haley CS, Hamilton A, Guy DR and others (2010) The susceptibility of Atlantic salmon fry to freshwater infectious pancreatic necrosis is largely explained by a major QTL. Heredity 105:318-327

Johansen LH, Sommer AI (1995) In vitro studies of infectious pancreatic necrosis virus infections in leucocytes isolated from Atlantic salmon (Salmo salar L.). Aquaculture 132: 91-95

Lapierre J, Larrivée D, Berthiaume L (1986) Influence of water temperature and fish age on mortality in brook trout (Salvelinus fontinalis) infected with infectious pancreatic necrosis virus (IPNV). Aquaculture 59:81-92

Larkin MA, Blackshields G, Brown NP, Chenna R and others (2007) Clustal W and Clustal X version 2.0. Bioinformatics 23:2947-2948

McColl KA, Davies KR, Young JG, Crane MStJ (2009) Aquatic birnavirus infections of finfish. Australian and New Zealand Standard Diagnostic Procedures, SubCommittee on Animal Health Laboratory Standards

Melbye HP, Christie KE (1994) Antigenic analysis of reference strains and Norwegian field strains of aquatic birnaviruses by the use of six monoclonal antibodies produced against infectious pancreatic necrosis virus N1 strain. J Fish Dis 17:409-415

National Veterinary Institute of Finland (1985) Annual report 1984: 76th year of operation. Valtion painatuskeskus, Helsinki

Nishizawa T, Kinoshita S, Yoshimizu M (2005) An approach for genogrouping of Japanese isolates of aquabirnaviruses in a new genogroup, VII, based on the VP2/NS junction region. J Gen Virol 86:1973-1978

Noble AC, Summerfelt ST (1996) Diseases encountered in rainbow trout cultured in recirculating systems. Annu Rev Fish Dis 6:65-92

Novoa B, Rivas C, Toranzo AE, Figueras A (1995) Pathogenicity of birnaviruses isolates from turbot (Scopthalmus maximus): comparison with reference serotypes of IPNV. Aquaculture 130:7-14

Okamoto N, Yasutomi R, Shibazaki H, Hanzawa S, Sano T (1987) The influence of immersing temperature for inoculation with IPNV and/or rearing temperature on mortality of rainbow trout fry postinfection. Bull Jpn Soc Sci

Editorial responsibility: Mark Crane, Geelong, Victoria, Australia
Fish 53:1125-1128

Ozaki A, Sakamoto T, Khoo S, Nakamura K, Coimbra MRM, Akutsu T, Okamoto N (2001) Quantitative trait loci (QTLs) associated with resistance/susceptibility to infectious pancreatic necrosis virus (IPNV) in rainbow trout (Oncorhynchus mykiss). Mol Genet Genomics 265:23-31

Reno PW (1999) Infectious pancreatic necrosis and associated aquatic birnaviruses. In: Woo PT, Bruno DW (eds) Fish diseases and disorders, Vol 3: Viral, bacterial, and fungal infections. CAB International, Wallingford, p 1-55

Rodriguez Saint-Jean S, Borrego J, Perez-Prieto SI (2003) Infectious pancreatic necrosis virus: biology, pathogenesis, and diagnostic methods. Adv Virus Res 62:113-165

> Ruane NM, McCarthy LJ, Swords D, Heshilwood K (2009) Molecular differentiation of infectious pancreatic necrosis virus isolates from farmed and wild salmonids in Ireland. J Fish Dis 32:979-987

> Santi N, Vakharia VN, Evensen $\varnothing$ (2004) Identification of putative motifs involved in the virulence of infectious pancreatic necrosis virus. Virology 322:31-40

Shivappa RB, Song H, Yao K, Aas-Eng A, Evensen Ø, Vakharia VN (2004) Molecular characterization of Sp serotype strains of infectious pancreatic necrosis virus exhibiting differences in virulence. Dis Aquat Org 61: 23-32

Smail DA, Munro ALS (1985) Infectious pancreatic necrosis virus persistence in farmed Atlantic salmon (Salmo salar). In: Ellis AE (ed) Fish and shellfish pathology. Academic Press, London, p 277-288

Smail DA, Bruno DW, Dear G, McFarlane LA, Ross K (1992) Infectious pancreatic necrosis (IPN) virus Sp serotype in farmed Atlantic salmon, Salmo salar L., post-smolts associated with mortality and clinical disease. J Fish Dis 15: 77-83

Song H, Santi N, Evensen Ø, Vakharia VN (2005) Molecular determinants of infectious pancreatic necrosis virus virulence and cell culture adaptation. J Virol 79:10289-10299

Taksdal T, Ramstad A, Stangeland K, Dannevig BH (1998) Induction of infectious pancreatic necrosis (IPN) in covertly infected Atlantic salmon, Salmo salar L., postsmolts by stress exposure, by injection of IPN virus (IPNV) and by cohabitation. J Fish Dis 21:193-204

> Tamura K, Stecher G, Peterson D, Filipski A, Kumar S (2013) MEGA6: molecular evolutionary genetics analysis version 6.0. Mol Biol Evol 30:2725-2729

Wolf K, Gravell M, Malsberger RG (1966) Lymphocystis virus: isolation and propagation in centrarchid fish cell lines. Science 151:1004-1005

Submitted: August 17, 2015; Accepted: November 12, 2015 Proofs received from author(s): January 11, 2016 